\title{
Refractory Indolent Adult Non-Hodgkin Lymphoma
}

National Cancer Institute

\section{Source}

National Cancer Institute. Refractory Indolent Adult Non-Hodgkin Lymphoma. NCI

Thesaurus. Code C148175.

Indolent adult non-Hodgkin lymphoma that is resistant to treatment. 